\title{
Characterisation of a bacterial galactokinase with high activity and broad substrate tolerance for chemoenzymatic synthesis of 6-aminogalactose-1-phosphate and analogues Dol:
}

10.1002/cbic.201700477

\section{Document Version \\ Accepted author manuscript}

Link to publication record in Manchester Research Explorer

Citation for published version (APA):

Huang, K., Parmeggiani, F., Pallister, E., Huang, C-J., Liu, F-F., Li, Q., Birmingham, W., Both, P., Thomas, B., Liu, L., Voglmeir, J., \& Flitsch, S. (2018). Characterisation of a bacterial galactokinase with high activity and broad substrate tolerance for chemoenzymatic synthesis of 6-aminogalactose-1-phosphate and analogues.

ChemBioChem: a European journal of chemical biology . https://doi.org/10.1002/cbic.201700477

\section{Published in:}

ChemBioChem: a European journal of chemical biology

\section{Citing this paper}

Please note that where the full-text provided on Manchester Research Explorer is the Author Accepted Manuscript or Proof version this may differ from the final Published version. If citing, it is advised that you check and use the publisher's definitive version.

\section{General rights}

Copyright and moral rights for the publications made accessible in the Research Explorer are retained by the authors and/or other copyright owners and it is a condition of accessing publications that users recognise and abide by the legal requirements associated with these rights.

\section{Takedown policy}

If you believe that this document breaches copyright please refer to the University of Manchester's Takedown Procedures [http://man.ac.uk/04Y6Bo] or contact uml.scholarlycommunications@manchester.ac.uk providing relevant details, so we can investigate your claim.

\section{OPEN ACCESS}




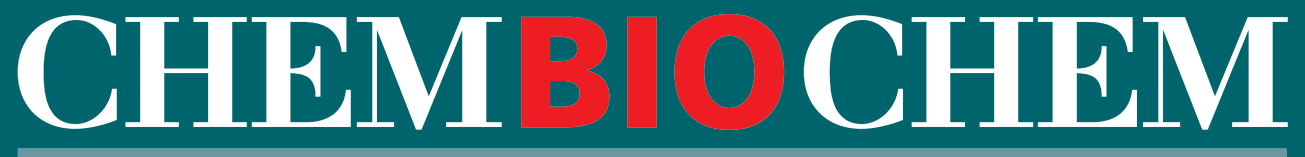

SYNTHETIC BIOLOGY \& BIO-NANOTECHNOLOGY

\section{Accepted Article}

Title: Characterisation of a bacterial galactokinase with high activity and broad substrate tolerance for chemoenzymatic synthesis of 6 -aminogalactose-1-phosphate and analogues

Authors: Kun Huang, Fabio Parmeggiani, Edward Pallister, ChuenJiuan Huang, Fang-Fang Liu, Qian Li, William R Birmingham, Peter Both, Baptiste Thomas, Li Liu, Josef Voglmeir, and Sabine Flitsch

This manuscript has been accepted after peer review and appears as an Accepted Article online prior to editing, proofing, and formal publication of the final Version of Record (VoR). This work is currently citable by using the Digital Object Identifier (DOI) given below. The VoR will be published online in Early View as soon as possible and may be different to this Accepted Article as a result of editing. Readers should obtain the VoR from the journal website shown below when it is published to ensure accuracy of information. The authors are responsible for the content of this Accepted Article.

To be cited as: ChemBioChem 10.1002/cbic.201700477

Link to VoR: http://dx.doi.org/10.1002/cbic.201700477 


\section{Characterisation of a bacterial galactokinase with high activity and broad substrate tolerance for chemoenzymatic synthesis of 6-aminogalactose-1-phosphate and analogues}

Kun Huang ${ }^{[\mathrm{a}]}$, Fabio Parmeggiani[a], Edward Pallister ${ }^{[\mathrm{a}]}$, Chuen-Jiuan Huang ${ }^{[\mathrm{a}]}$, FangFang Liu ${ }^{[b]}$, Qian Li ${ }^{[b]}$, William R. Birmingham ${ }^{[a]}$, Peter Both ${ }^{[a]}$, Baptiste Thomas ${ }^{[a]}$, Li Liu $^{[b]}$, Josef Voglmeir ${ }^{[b]}$, Sabine L. Flitsch*[a]

[a] K. Huang, Dr. F. Parmeggiani, E. Pallister, Dr. C. J. Huang, Dr. W. R. Birmingham, Dr. P. Both, Dr. B. Thomas, Prof. S. L. Flitsch.

Manchester Institute of Biotechnology, School of Chemistry, The University of Manchester, 131 Princess Street, Manchester M1 7DN, United Kingdom.

E-mail: sabine.flitsch@manchester.ac.uk

[b] F. F. Liu, Q. Li, Prof. L. Liu, Prof. J. Voglmeir.

Glycomics and Glycan Bioengineering Research Center (GGBRC), College of Food Science and Technology, Nanjing Agricultural University, Nanjing 210095, China.

E-mail: josef.voglmeir@njau.edu.cn 


\begin{abstract}
Glycosyl phosphates are important intermediates in many metabolic pathways and are substrates for diverse carbohydrate active enzymes. There is a need to develop libraries of structurally similar analogues that can be used as selective chemical probes in glycomics. Here we explore chemoenzymatic cascades for the fast generation of glycosyl phosphate libraries without protecting group strategies. The key enzyme is a new bacterial galactokinase (LgGalK) cloned from Leminorella grimontii which was produced in $E$. coli and shown to catalyse 1-phosphorylation of galactose. LgGalK displayed a broad substrate tolerance, being able to catalyse the 1-phosphorylation of a number of galactose analogues, including 3-deoxy-3fluorogalactose and 4-deoxy-4-fluorogalactose, which are first reported substrates for wild-type galactokinase. LgGalK and galactose oxidase variant $M_{1}$ were combined in a one-pot two-step system to synthesise 6-oxogalactose-1-phosphate and 6-oxo-2-fluorogalactose-1-phosphate, which were subsequently utilised to produce a panel of 30 substituted 6-aminogalactose-1-phosphate derivatives by chemical reductive amination in a one-pot three-step chemoenzymatic process.
\end{abstract}

\section{Table of Contents text}

A highly active bacterial galactokinase (LgGalK) from Leminorella grimontii was identified and characterised, showing broad substrate specificity towards different nucleotide phosphates and monosaccharides. This enzyme, in combination with galactose oxidase variant $M_{1}$, was also employed in the chemoenzymatic synthesis of a panel of 6-aminogalactose-1-phosphate analogues.

\section{Graphical abstract}

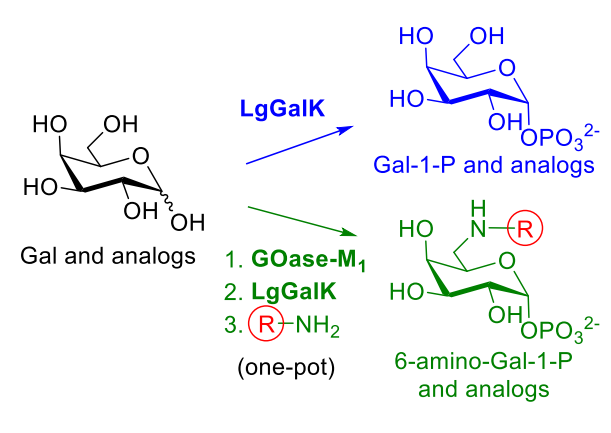

\title{
Keywords
}

sugars $\bullet$ biocatalysis • kinases $\bullet$ oxidoreductases $\bullet$ carbohydrates 


\section{Introduction}

Glycosyl phosphates are critically important in carbohydrate metabolism, and participate in primary metabolism (e.g., gluconeogenesis and glycolysis), ${ }^{[1]}$ as well as in secondary metabolism (e.g., glycosylated natural product synthesis).[2] Furthermore, they can be involved in the regulation of metabolic processes. ${ }^{[3]}$ In glycan biosynthesis, glycosyl-1-phosphates are key precursors to complex glycans, acting as natural glycosylation agents.

Galactose-1-phosphate (Gal-1-P, 2) is a key intermediate in the metabolism of galactose (Gal, 1). It can be used as an activated sugar donor to synthesise uridine diphosphate galactose (UDP-Gal, 3) either by UDP-sugar pyrophosphorylase (USP) (Scheme 1a) in the salvage pathway, ${ }^{[4-6]}$ or by galactose-1-phosphate uridyltransferase (GalU) and UDP-glucose-4-epimerase (GalE) in the Leloir pathway (Scheme 1b). ${ }^{[7]}$ The resulting product 3 is a sugar donor for diverse galactosyltransferases. Phosphate 2 can also be used by phosphorylases to produce galactosides (Scheme 1c) in vitro. For example, BiGalHexNAcP is able to utilise 2 and its analogues to generate $\beta-1,3$-linked galactosides and their derivatives containing T-antigen and galacto- $\mathrm{N}$-biose. ${ }^{[8]}$ Therefore, stereoselective glycosidic phosphorylation can be considered as the key activation step for glycosylation.

The chemical synthesis of glycosyl phosphates is possible, but it requires several protection and deprotection steps. In addition, regio- and stereoselectivity can be difficult to control[9-11] and overall yields are generally low. On the other hand, enzymatic synthesis requires only one step from the free sugar, and is generally highly regio- and stereoselective. Enzymatic phosphorylation can also be utilised in one-pot enzymatic and chemoenzymatic cascades, which have become of great interest recently. ${ }^{[12,13]}$

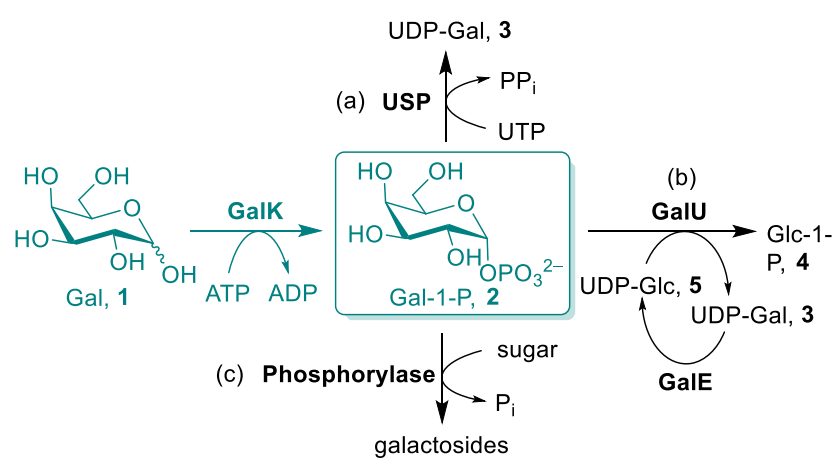

Scheme 1. The role of galactokinase in sugar synthesis as a gateway enzyme for the production of Gal-1-P (2), which is a precursor of multiple biosynthetic pathways: (a) salvage pathway biosynthesis, (b) Leloir pathway biosynthesis; (c) phosphorylase catalysed galactoside synthesis. 
Galactokinase (EC 2.7.1.6, GalK), which belongs to the GHMP kinase family (galactokinase, homoserine kinase, mevalonate kinase and phosphomevalonate kinase), ${ }^{[14]}$ catalyses the ATP-dependent phosphorylation at the anomeric carbon of 1 to produce 2 (Scheme 1). ${ }^{[15]}$ A variety of galactokinases from diverse organisms including both eukaryotes ${ }^{[16-20]}$ and prokaryotes ${ }^{[21-24]}$ have been identified and characterised, exhibiting different biochemical properties and substrate specificities. Several bacterial galactokinases, including EcGalK, ${ }^{[21]}$ SpGalK, ${ }^{[22]}$ BiGalK, ${ }^{[23]}$ and MtGalK, ${ }^{[24]}$ showed robust catalytic activity and demonstrated their use in the biocatalytic synthesis of nucleotide sugars, ${ }^{[25]}$ as well as biologically significant glycans and their analogues, ${ }^{[26,27]}$ but the substrate range has been limited to analogues that are structurally closely related to the parent sugar, often differing by only a single substitution.

Herein, a novel bacterial galactokinase from Leminorella grimontii (LgGalK) was overproduced and biochemically characterised. Its substrate specificity was investigated, which revealed a broad tolerance, making it suitable for the synthesis of several analogues of 2 . We also demonstrate its use in the synthesis of a panel of substituted 6-aminogalactose-1-phosphate in one-pot chemoenzymatic cascades, in combination with a galactose oxidase (GOase) variant and a chemical reductive amination step. We showed that in a simple three-step procedure, a diverse library of complex sugar phosphate analogues can be generated, providing a useful chemical probe toolkit for glycomics studies.

\section{Results and Discussion}

\section{Cloning, expression and purification of LgGalK}

The galactokinase gene (1167 bp) was amplified from the genomic DNA of Leminorella grimontii. A phylogenetic analysis (Figure 1) revealed that the closest characterised homologue of LgGalK is EcGalK from E. coli (68\% identity), followed by MtGalK from Meiothermus taiwanensis (42\%), while BiGalK from Bifidobacterium infantis was found to possess the lowest identity (32\%). According to the amino acid sequence alignment (Supporting Information, Figure S1), all three typically conserved glycine-rich functional motifs of GHMP superfamily members were found in LgGalK, consistent with GalK belonging to this class. 


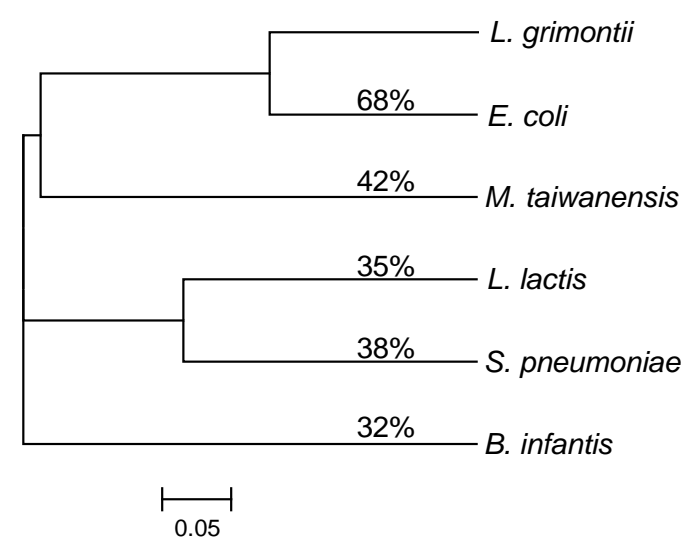

Figure 1. Phylogenetic tree of characterised galactokinases.

The open reading frame coding for LgGalK was cloned into a pET-30a vector with Nterminal His-tag. The recombinant protein was produced in E. coli BL21(DE3) cells (induced with $1 \mathrm{mM} \mathrm{IPTG}$ at $18^{\circ} \mathrm{C}$ for 20 hours) and purified by nickel affinity chromatography. The overall yield of active purified protein was $32.8 \mathrm{mg} / \mathrm{L}$ cell culture (purification factor 12.3). SDS-PAGE analysis (Figure 2) indicates that the purified LgGalK has an apparent molecular weight of around $40 \mathrm{kDa}$, matching with the theoretical molecular mass of $42 \mathrm{kDa}$.

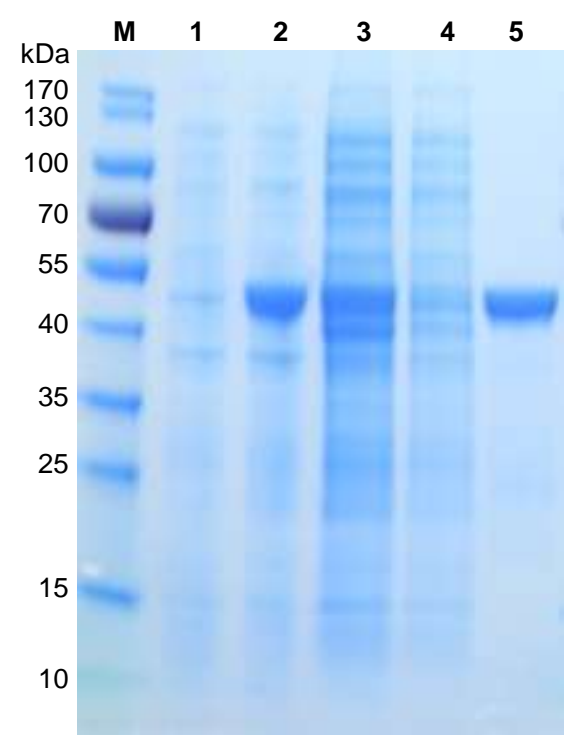

Figure 2. SDS-PAGE analysis of LgGalK. M: molecular weight marker; 1: before induction; 2: after induction; 3: supernatant; 4: flow-through; 5: purified LgGalK.

\section{Biochemical characterisation of LgGalK}

In order to characterise the properties of LgGalK, its activity against $\mathbf{1}$ was measured by the DNS assay ${ }^{[19]}$ under a range of different conditions. The optimal temperature was found to be $50^{\circ} \mathrm{C}$, with high activity between 40 and $55^{\circ} \mathrm{C}$ (Figure $3 \mathrm{a}$ ). Enzymatic activity gradually increased from pH 6.0 to 9.0, but sharply decreased at 
pH 10.0 (Figure 3b). Similar to other characterised galactokinases, LgGalK requires $\mathrm{Mg}^{2+}$ as a cofactor, and the effect of several other divalent metal ions was also tested (Figure $3 \mathrm{c}$ ). $\mathrm{Cu}^{2+}$ and $\mathrm{Zn}^{2+}$ decreased kinase activity considerably, while $\mathrm{Ni}^{2+}$ and $\mathrm{Fe}^{2+}$ could substitute $\mathrm{Mg}^{2+}$ as cofactor with almost no reduction of activity. Furthermore, the optimal $\mathrm{Mg}^{2+}$ concentration was determined to be around $1 \mathrm{mM}$, with very modest decrease in activity as the $\mathrm{Mg}^{2+}$ concentration increased (Figure 3d). The apparent kinetic constants of LgGalK towards 1 were determined using the DNS assay by varying the concentration of $1(1,2,4,6,8 \mathrm{mM})$ with saturation concentration of ATP $(20 \mathrm{mM})$. The initial velocity was obtained by measuring the slope value of the linear phase in the progress curve. The Michaelis-Menten plots (Supporting Information Figure S2) were generated to obtain the kinetic parameters for $1\left(K_{\mathrm{M}}=1.3 \pm 0.4 \mathrm{mM}, k_{\mathrm{cat}}=23.7 \pm 1.8 \mathrm{~s}^{-1}, k_{\mathrm{cat}} / K_{\mathrm{M}}=18.1 \mathrm{mM}^{-1} \cdot \mathrm{s}^{-1}\right)$ and ATP $\left(K_{\mathrm{M}}=\right.$ $1.5 \pm 0.4 \mathrm{mM}, k_{\mathrm{cat}}=32.9 \pm 0.2 \mathrm{~s}^{-1}, k_{\mathrm{cat}} / K_{\mathrm{M}}=21.3 \mathrm{mM}^{-1} \cdot \mathrm{s}^{-1}$ ). Compared to EcGalK (Gal, $K_{M}=2.1 \mathrm{mM}, k_{\text {cat }} / K_{M}=0.552 ;$ ATP, $\left.K_{M}=2.5 \mathrm{mM}, k_{\text {cat }} / K_{M}=0.464 \mathrm{mM}^{-1} \cdot \mathrm{s}^{-1}\right)_{\text {, }}$, 11$]$ LgGalK has better affinity and higher catalytic efficiency towards both 1 and ATP. However, BiGalK showed lower $K_{M}$ value and higher $k_{\text {cat }} / K_{M}$ towards $1\left(K_{M}=0.895\right.$, $\left.k_{\text {cat }} / K_{M}=164 \mathrm{mM}^{-1} \cdot \mathrm{s}^{-1}\right) \cdot{ }^{[23]}$ Overall, kinetic data of LgGalK towards both 1 and ATP are comparable with those reported for GalKs, including EcGalK, BiGalK and SpGalK.

(a)

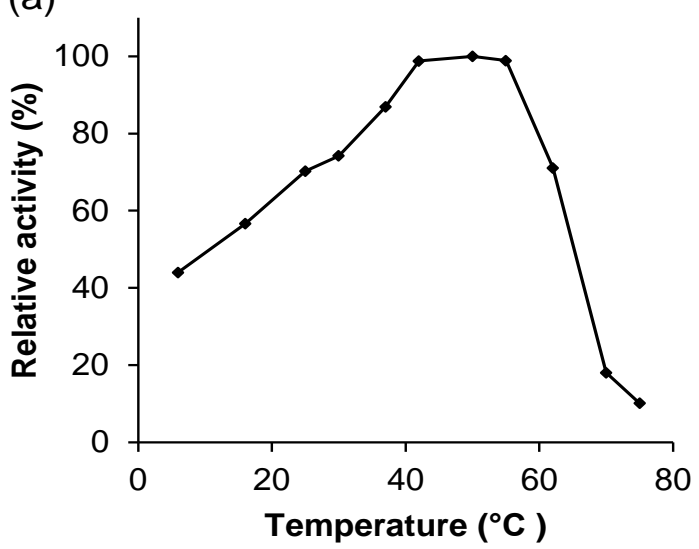

(c)

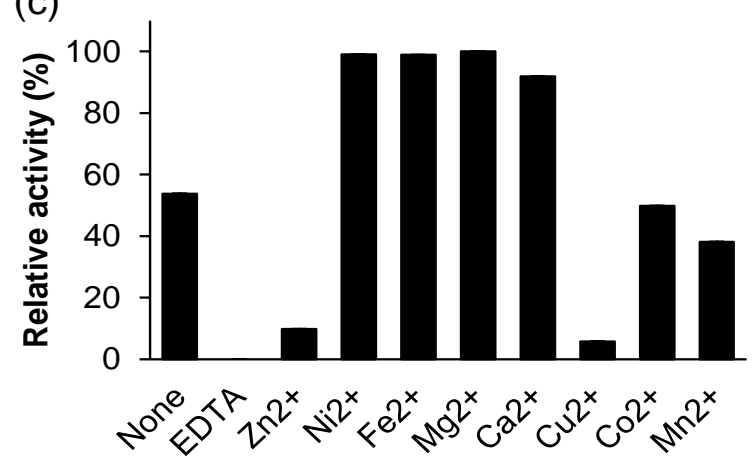

Divalent metal ions (b)

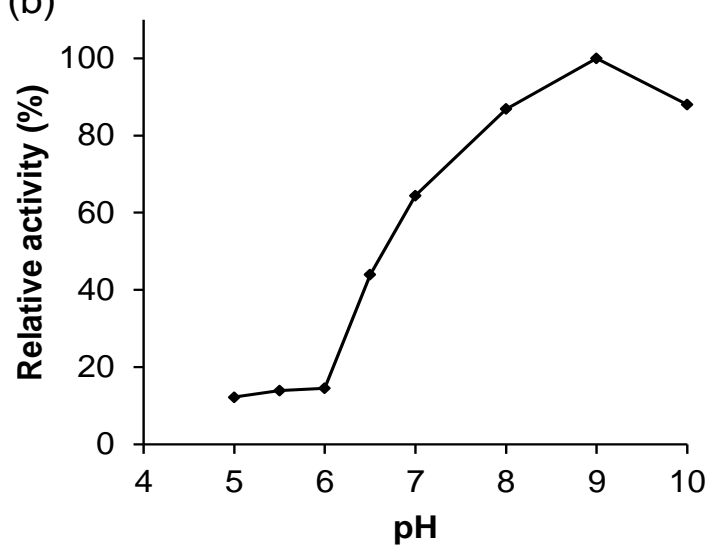

(d)

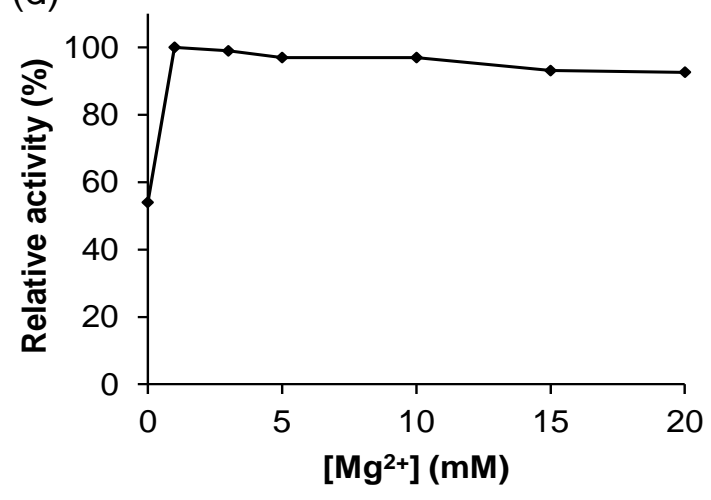

Figure 3. Biochemical characterisation of LgGalK: (a) temperature-activity profile, (b) pH-activity profile, (c) effect of divalent metal ions, (d) effect of $\mathrm{Mg}^{2+}$ concentration. 
Table 1. Substrate specificity of LgGalK towards different monosaccharides.

\begin{tabular}{|c|c|c|c|c|c|c|c|}
\hline Substrate & $\mathrm{MS}^{[\mathrm{a}]}$ & $T_{L C}[\mathrm{a}]$ & $\begin{array}{c}\text { Conv. } \\
(\%)\end{array}$ & Substrate & $\mathbf{M S}^{\left[{ }^{[a]}\right.}$ & $T^{\prime} C^{[a]}$ & $\begin{array}{c}\text { Conv. } \\
(\%)\end{array}$ \\
\hline (O) & + & + & $72^{[\mathrm{b}]}$ & $\underbrace{\mathrm{N}_{3}}_{\substack{\mathrm{OH}_{2} \mathrm{OH} \\
\mathrm{Gal}_{3}, 17}}$ & - & - & n.a. \\
\hline$\underbrace{\mathrm{OH}}_{\substack{\mathrm{NH}_{2}^{2} \mathrm{OH} \\
\mathrm{GalN}, 6}}$ & + & + & $68^{[\mathrm{b}]}$ & ${ }_{\mathrm{HO}}^{\mathrm{HO}}$ & + & + & $41^{[b]}$ \\
\hline$\underbrace{\mathrm{H}^{2} \mathrm{OH}}_{\mathrm{GalA}, 7}$ & - & - & n.a. & & - & - & n.a. \\
\hline$\underbrace{N_{0}^{O H}}_{\substack{N H A C \\
\text { GalNAc, } 8}}$ & - & - & n.a. & $\underbrace{\mathrm{NO}}_{\mathrm{GICNAc}, 20}$ & - & - & n.a. \\
\hline Gal2D, 9 & + & + & $<5^{[\mathrm{b}]}$ & $\underbrace{\mathrm{OH}}_{\substack{\mathrm{HONN}, 21 \\
\mathrm{NICH}_{2}^{2}}}$ & - & - & n.a. \\
\hline $3 \mathrm{D}, 10$ & + & + & $19^{[b]}$ & $\underbrace{\mathrm{H}^{2} \mathrm{OH}}_{\mathrm{GICA}, 22}$ & - & - & n.a. \\
\hline 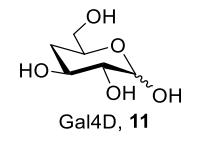 & + & + & $<5^{[b]}$ & $\underbrace{\mathrm{O} \mathrm{H}^{2} \mathrm{OH}}_{\mathrm{Ara}, 23}$ & - & - & n.a. \\
\hline$\underbrace{}_{\mathrm{OH}_{\mathrm{O}} \mathrm{O}^{2} \mathrm{OH}}$ & + & + & $57^{[\mathrm{b}]}$ & OH $_{\text {L-Fuc, } 24}$ & - & - & n.a. \\
\hline$\underbrace{\mathrm{FO}}_{\mathrm{Gal2F}, 13}$ & + & + & $80^{[c]}$ & ${ }_{\mathrm{Man,2}} 25 \mathrm{OH}$ & - & - & n.a. \\
\hline$\underbrace{\mathrm{OH}}_{\substack{\mathrm{OH} \mathrm{H}^{2} \mathrm{OH} \\
\text { Gal }, 14}}$ & + & + & $27^{[c]}$ & ${ }_{\substack{\mathrm{OH} \\
\mathrm{Fru}, 26}}^{\mathrm{HO}} \underbrace{\mathrm{O} O}_{\mathrm{OH}}$ & - & - & n.a. \\
\hline$\underbrace{}_{\substack{\mathrm{OH}^{2} \mathrm{O} \\
\text { Gal4F, }}}$ & + & + & $21^{[c]}$ & $\underbrace{\mathrm{O}, \mathrm{OH}}_{\mathrm{Xyl}, 27}$ & - & - & n.a. \\
\hline$\underbrace{}_{\mathrm{OH}_{\mathrm{O} \mathrm{H}^{2} \mathrm{O}}}$ & + & + & $28^{[c]}$ & & & & \\
\hline
\end{tabular}

[a] + : evidence of product formation; - : no evidence of product formation; n.a. : no activity;

[b] conversion determined by the DNS assay;

${ }^{[c]}$ conversion determined by ${ }^{19} \mathrm{~F}$ NMR. 


\section{Substrate specificity study of LgGalK}

Initial activity studies of LgGalK towards different sugar substrates were carried out using method described by Duan et al., based on the measurement of the reaction by-product ADP. ${ }^{28]}$ Evidence of phosphorylation activity of LgGalK against galactose, galactosamine and talose was observed with this preliminary screening assay (Supporting Information, Figure S3). Thereafter, the formation of $\mathbf{2}$ from $\mathbf{1}$ was monitored by TLC and further confirmed by HRMS. Furthermore, ${ }^{13} \mathrm{C}$-labelled galactose $\left({ }^{13} \mathrm{C}_{6}-\mathbf{1}\right)$ was used as substrate and ${ }^{13} \mathrm{C}$ NMR analysis confirmed the formation of ${ }^{13} \mathrm{C}_{6}-2$ (Supporting Information) The conversion was also measured by the DNS assay, giving a value of $72 \%$ (Table 1) under the optimised conditions identified above (except for the concentration of $\mathrm{Mg}^{2+}$ which was increased to $5 \mathrm{mM}$ ).

In order to study the substrate specificity, 22 different monosaccharides (6-27), including deoxygalactoses 9-12 and deoxyfluorogalactoses 13-16, were tested as substrates of LgGalK (Table 1). The formation of products in the LgGalK reactions was monitored by TLC and HRMS (Supporting Information). LgGalK was found to have some activity against 10 substrates to generate the corresponding sugar-1phosphates: galactosamine 6, 2-deoxygalactose 9, 3-deoxygalactose 10, 4deoxygalactose 11, 6-deoxygalactose 12, 2-deoxy-2-fluorogalactose 13, 3-deoxy-3fluorogalactose 14, 4-deoxy-4-fluorogalactose 15, 6-deoxy-6-fluorogalactose 16 and talose 18. Conversions for fluorinated substrates were determined by ${ }^{19} \mathrm{~F}$ NMR (Supporting Information) and with the DNS assay. As shown in Table 1, Gal2F 13 was the best substrate giving 80\% conversion, followed by GaIN 6 (68\%), however only weak or even no activity was identified for Gal2D 9 and GaINAc 8, respectively. This is consistent with previous observations that galactose derivatives substituted at the C-2 position by small polar groups are substrates for GalKs. Furthermore, 57\% and $28 \%$ conversions were measured for Gal6D 12 and Gal6F 16, while no product was found for GalA 7, demonstrating that LgGalK has a similar tolerance towards C6 modifications compared to C-2. Interestingly, Gal3F 14 and Gal4F 15 also serve as substrates for LgGalK (albeit with low activity), which has not been reported previously for wild-type galactokinases.

Furthermore, the phosphate donor substrate range was examined by using several nucleotide phosphates (UTP, GTP, CTP, TTP, ADP, UDP, GDP) and sodium pyrophosphate instead of ATP. LgGalK showed high activity towards all four nucleotide triphosphates (Supporting Information). However, very low or no activity was found for nucleotide diphosphates and sodium pyrophosphate.

\section{Chemoenzymatic synthesis of 6-aminogalactose-1-phosphate analogues}

Galactose oxidase (GOase, EC 1.1.3.9), belonging to the class of copper-dependent alcohol oxidases, is able to oxidise specifically the C-6 hydroxyl group of galactose to generate an aldehyde group, which can be used as a reactive functional handle for further chemistry. In particular, variant $M_{1}\left(G O a s e-M_{1}\right)^{[29]}$ was selected as it was 
engineered to retain high activity against galactose and improved expression in $E$. coli, making it the most suitable candidate for biocatalysis. To demonstrate the potential of LgGalK as a highly active and promiscuous enzyme for biocatalytic cascade applications, we explored its combination with GOase- $\mathrm{M}_{1}$, to access a broader range of modified derivatives of 2 .

GOase-M $\mathrm{M}_{1}$ and LgGalK were combined in a one-pot system to synthesise 6oxogalactose-1-phosphate (GalO-1-P, 28) from 1. When the two enzymes were added to the reaction mixture simultaneously, only the formation of Gal-1-P 2 was observed (by HRMS, data not shown), suggesting that the sugar phosphate is not a substrate for GOase-M1. However, carrying out the same reaction in a one-pot twostep fashion, by adding LgGalK only after completion of the oxidation by GOase-M (Scheme 3), formation of the desired product $\mathbf{3 0}$ was detected by HRMS and further confirmed by ${ }^{13} \mathrm{C}$ NMR starting from ${ }^{13} \mathrm{C}_{6}-1$ (Supporting Information). Encouraged by this result, we also tested the other substrates for LgGalK identified above $(6,10,12-$ 16 and 18), in a one-pot two-step system. Only 13 was efficiently converted to 6-oxo2-deoxy-2-fluorogalactose-1-phosphate (GalO2F-1-P, 31) as monitored by HRMS (Supporting Information).

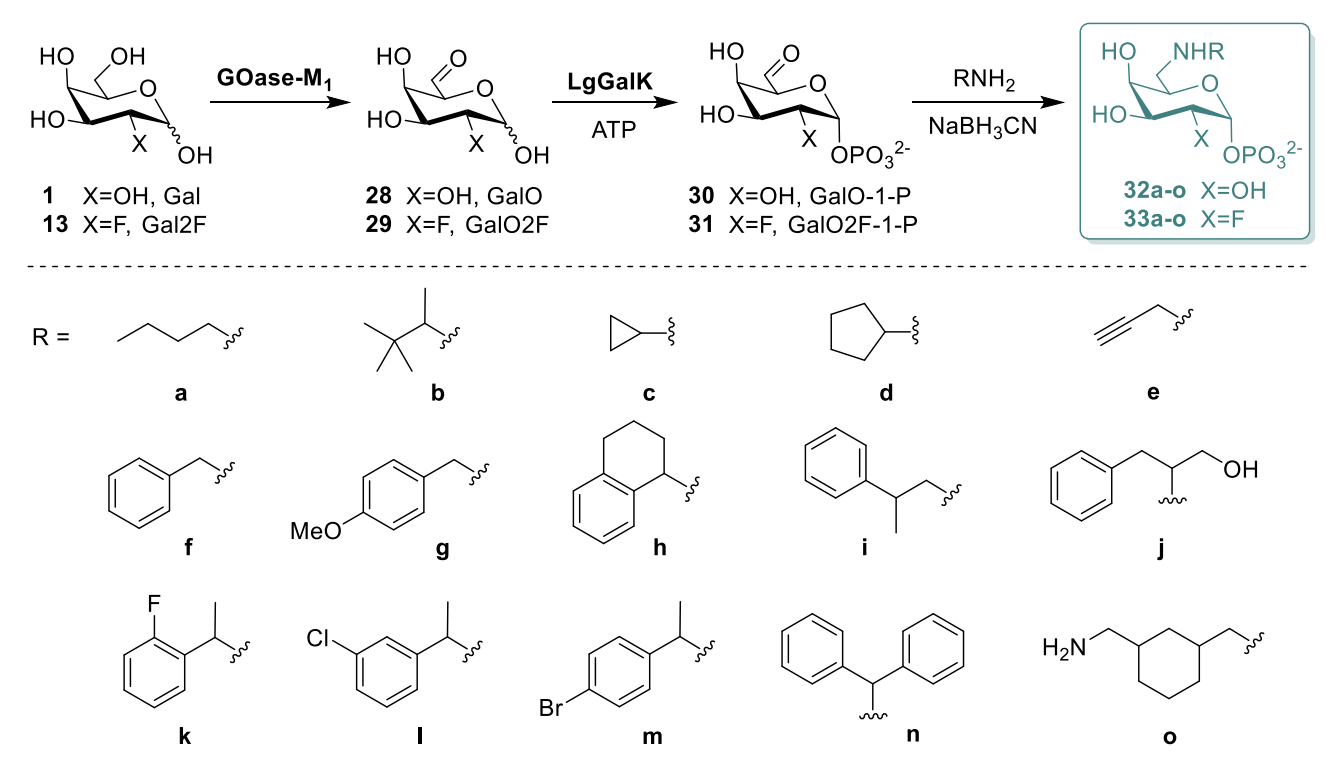

Scheme 2. Chemoenzymatic synthesis of 6-aminogalactose-1-phosphate analogues 32a-0 and 33a$\mathbf{o}$. With diamine $\mathbf{0}$, reductive amination proceeded only at one amino group.

The reactivity of the aldehyde group of 30-31 can be exploited to perform further chemical derivatisations, most prominently reductive aminations, as previously demonstrated. ${ }^{\left[{ }^{[0-32]}\right.}$ Therefore, we extended our procedure to a one-pot three-step protocol by including a chemical reductive amination with $\mathrm{NaBH}_{3} \mathrm{CN}$ and a panel of 15 different amines (Scheme 3), in the same aqueous medium after the biotransformation. The formation of all 30 different 6 -amino substituted products 32a0 and 33a-o were confirmed by HRMS (Table S2, Supporting Information), giving 
access to a wide array of functionally diverse modified monosaccharides to be tested against diverse carbohydrate-binding proteins and enzymes.

\section{Conclusion}

A new bacterial galactokinase (LgGalK) with high catalytic efficiency and broad substrate specificity was overproduced and characterised. The effects of temperature, $\mathrm{pH}$ and divalent metal ions on its activity were investigated, leading to the identification of the optimal biochemical conditions: $50^{\circ} \mathrm{C}, \mathrm{pH} 9.0,1 \mathrm{mM} \mathrm{Mg}^{2+}$. Kinetic studies of $\mathrm{LgGalK}$ towards Gal afforded the kinetic constants for the reaction (in particular $K_{\mathrm{M}}=1.3 \pm 0.4 \mathrm{mM}$ and $k_{\text {cat }}=23.7 \pm 1.8 \mathrm{~s}^{-1}$ ). LgGalK was shown to catalyse the anomeric carbon phosphorylation of a broad variety of monosaccharides (6, 9-16 and 18) to yield the corresponding sugar-1-phosphates. Additionally, LgGalK could phosphorylate 6-oxo derivatives 28 and 29, produced by GOase-M1. Combination with chemical reductive amination in a one-pot three-step chemoenzymatic system afforded a panel of 30 different 6-aminogalactose-1phosphate analogues (32a-0, 33a-0).

\section{Experimental section}

\section{General}

Leminorella grimontii strain DSMZ 5078 (lyophilized culture pellet) was purchased from DSMZ (Germany). Gene primers were synthesised by Genescript (Nanjing, China). Primestar HS DNA polymerase is from Takara (Dalian, China). Restriction enzymes (EcoRl, Xhol) are from Thermo Fisher Scientific (Shanghai, China). E. coli BL21(DE3) cells, E. coli Top10 cells and the pET30a vector are from Novagen. Galactose oxidase variant $\mathrm{M}_{1}$ was prepared as described previously. ${ }^{[32]}$

Deoxygalactoses 10-11 and deoxyfluorogalactoses 13-16 were supplied by Carbosynth (United Kingdom). Other chemical reagents and solvents were purchased from Sigma-Aldrich and used without further purification, unless stated otherwise.

\section{Analytical methods}

${ }^{13} \mathrm{C}$ and ${ }^{19} \mathrm{~F}$ NMR spectra were recorded in $\mathrm{H}_{2} \mathrm{O} / \mathrm{D}_{2} \mathrm{O}$ using a Bruker AV400 (400, 101 and $376 \mathrm{MHz}$ respectively) spectrometers and $\operatorname{AV} 500(500,126$ and $470 \mathrm{MHz}$ respectively). ${ }^{13} \mathrm{C}$ chemical shifts $(\delta)$ are quoted in ppm relative to residual solvent peaks as appropriate. ${ }^{19} \mathrm{~F}$ spectra were externally referenced to $\mathrm{CFCl}_{3}$. The coupling constants $(J)$ were recorded in Hertz $(\mathrm{Hz})$. HRMS data were obtained from a Bruker APEX III FT-ICR-MS. Samples were run in HPLC grade MeOH or MeCN. 


\section{Gene cloning}

Genomic DNA was isolated from lyophilized Leminorella grimontii culture pellets based on the method described by Mahuku. ${ }^{[33]}$ The DNA primer sequences used to amplify the gene coding region of the putative galactokinase (DNA GeneBank accession number: JMPN1000011.1) were designed according to genomic sequence as follows: forward primer 5'-GGAATTCATGAACGCGCTCGTTGCC-3' (ECORI restriction site underlined), reverse primer 5'CCGCTCGAGTTAACATAGGCTGGCTCCTGCT-3' (Xhol restriction site underlined). DNA amplification was performed utilising Primestar HS DNA polymerase (Takara, Dalian, China) according to the manufacturer's instructions. Briefly, 28 PCR cycles consisting of denaturation at $95^{\circ} \mathrm{C}$ for $10 \mathrm{sec}$, annealing at $55^{\circ} \mathrm{C}$ for $30 \mathrm{sec}$, and elongation at $72^{\circ} \mathrm{C}$ for 2 min were performed to amplify the gene. Restriction endonucleases EcoRI and Xhol (Thermo Fisher Scientific, Shanghai, China) were used to digest PCR products simultaneously, which subsequently were ligated into a pre-digested $\mathrm{pET}-30 \mathrm{a}$ expression vector (Novagen). The resulting construct ( $\mathrm{pET}$ 30a-LgGalK) was transformed into E. coli TOP10 competent cells and transformants were selected on LB medium supplemented with $50 \mu \mathrm{g} \mathrm{mL}{ }^{-1}$ kanamycin. Colonies harboring the expected plasmid construct were screened by DNA sequencing (Genscript, Nanjing) and used for further experiments. Plasmid extraction, restriction endonuclease digestion, DNA purification, ligation, and transformation procedures were executed according to the manufacturer's instructions.

\section{Protein production and purification}

The pET-30a-LgGalK vector was transformed into E. coli BL21(DE3) for protein expression. E.coli transformants containing the vector were grown in LB medium at $37^{\circ} \mathrm{C}$ until the optical density at $600 \mathrm{~nm}\left(\mathrm{OD}_{600}\right)$ of the culture reached 0.5-1.0. Protein expression was induced by addition of isopropyl-1-thio- $\beta-D-$ galactopyranoside (IPTG, final concentration $1 \mathrm{mM}$ ), followed by incubation at $18^{\circ} \mathrm{C}$ for $20 \mathrm{~h}$ with shaking at $250 \mathrm{rpm}$. The cells were harvested by centrifugation at 6000 $\mathrm{rpm}$ at $4^{\circ} \mathrm{C}$ for $20 \mathrm{~min}$, then resuspended in lysis buffer $(100 \mathrm{mM} \mathrm{NaCl}, 50 \mathrm{mM} \mathrm{Tris,}, 1 \%$ $\mathrm{v} / \mathrm{v}$ Triton $\mathrm{X}-100, \mathrm{pH} 8.0)$. A protease inhibitor cocktail ( $1 \% \mathrm{v} / \mathrm{v})$ was subsequently added to the cell suspension. The cells were disrupted by sonication (20 sec on, 20 sec off, 20 cycles). The supernatant of cell lysate was obtained by centrifugation at $15000 \mathrm{rpm}$ at $4^{\circ} \mathrm{C}$ for $20 \mathrm{~min}$. LgGalK was purified by nickel affinity chromatography on an ÄKTA purification system equipped with a HisTrap ${ }^{T M}$ FF $5 \mathrm{ml} \mathrm{Ni}^{2+}-\mathrm{NTA}$ affinity column (GE Healthcare). The supernatant was loaded on column pre-equilibrated with 5 column volumes of binding buffer $(50 \mathrm{mM}$ Tris, $500 \mathrm{mM} \mathrm{NaCl}, 10 \mathrm{mM}$ imidazole, $\mathrm{pH}$ 8.0). Subsequently, the column was washed with 20 column volumes of binding buffer and 10 column volumes of washing buffer $(50 \mathrm{mM}$ Tris, $500 \mathrm{mM}$ $\mathrm{NaCl}, 50 \mathrm{mM}$ imidazole, $\mathrm{pH}$ 8.0). The target protein was eluted with elution buffer (50 $\mathrm{mM}$ Tris, $500 \mathrm{mM} \mathrm{NaCl}, 300 \mathrm{mM}$ imidazole, $\mathrm{pH}$ 8.0). The fractions containing purified protein were collected and concentrated by centrifugation at $4000 \mathrm{rpm}$ at $4^{\circ} \mathrm{C}$ for $1 \mathrm{~h}$, then dialyzed against dialysis buffer ( $20 \mathrm{mM}$ Tris, $\mathrm{pH} 8.0)$ overnight at $4^{\circ} \mathrm{C}$. The purified enzyme was either snap-frozen using liquid nitrogen or dissolved in $18 \%$ glycerol before stored at $-80^{\circ} \mathrm{C}$ for further experiments. Protein concentration was measured by the Pierce ${ }^{\circledR}$ BCA Protein Assay Kit (Thermo Fisher Scientific) and SDS-polyacrylamide gel electrophoresis (SDS-PAGE) was performed to evaluate protein purity. The overall yield of active protein was $32.8 \mathrm{mg} / \mathrm{L}$ cell culture $(\sim 7 \mathrm{mg} / \mathrm{g}$ 
cell wet weight). Initial activity tests of purified LgGalK was performed using the method described by Duan et al.[28] (Supporting Information, Figure S3).

\section{Biochemical characterisation of LgGalK}

Influence of temperature. The enzymatic reaction was performed for $30 \mathrm{~min}$ in a total volume of $50 \mu \mathrm{L}$, containing $1(8 \mathrm{mM})$, ATP $(10 \mathrm{mM}), \mathrm{MgCl}_{2}(5 \mathrm{mM})$, Tris buffer $(50 \mathrm{mM}, \mathrm{pH}$ 8.0), LgGalK $(13.6 \mu \mathrm{g})$. The mixtures were quenched by adding $100 \mu \mathrm{L}$ DNS reagent (1 g 3,5-dinitrosalicylic acid and $30 \mathrm{~g} \mathrm{KNaC}_{4} \mathrm{H}_{4} \mathrm{O}_{6} \cdot 4 \mathrm{H}_{2} \mathrm{O}$ dissolved in $100 \mathrm{~mL} 0.4 \mathrm{M} \mathrm{NaOH}$ ), and then heated at $95-100^{\circ} \mathrm{C}$ for $5 \mathrm{~min}$. Subsequently, they were cooled on ice and further transferred into 96-well plates. Absorbance at $575 \mathrm{~nm}$ was measured and the conversion rate was calculated as described previously. ${ }^{[21]}$ All assays were executed in triplicates.

Influence of $\mathrm{pH}$. The enzymatic reaction was performed at $50^{\circ} \mathrm{C}$ for $30 \mathrm{~min}$ in a total volume of $50 \mu \mathrm{L}$, containing $1(8 \mathrm{mM})$, ATP $(10 \mathrm{mM}), \mathrm{MgCl}_{2}(5 \mathrm{mM})$, LgGalK $(13.6 \mu \mathrm{g})$ in different buffers (50 mM, pH varying between 5.0 and 10.0). Quenching and assay were performed as described above. All reactions were performed in triplicates.

Influence of divalent metal ions. The enzymatic reaction was performed at $50^{\circ} \mathrm{C}$ for $30 \mathrm{~min}$ in a total volume of $50 \mu \mathrm{L}$, containing 1 (8 mM), ATP $(10 \mathrm{mM})$, LgGalK $(13.6 \mu \mathrm{g})$ in Tris buffer $\left(50 \mathrm{mM}, \mathrm{pH}\right.$ 9.0). Different metal ions $\left(\mathrm{Zn}^{2+}, \mathrm{Ni}^{2+}, \mathrm{Fe}^{2+}, \mathrm{Ca}^{2+}\right.$, $\mathrm{Cu}^{2+}, \mathrm{Co}^{2+}, \mathrm{Mn}^{2+}$ ) or EDTA (5 mM) or different concentrations of $\mathrm{Mg}^{2+}$ ions $(1,3,5$, $10,15,20 \mathrm{mM}$ ) were added to the buffer. Quenching and assay were performed as described above. All reactions were performed in triplicates.

Kinetic study. The enzymatic activity assay was carried out at $50^{\circ} \mathrm{C}$ in a total volume of $50 \mu \mathrm{L}$, containing $1(1,2,4,6,8 \mathrm{mM})$, ATP $(20 \mathrm{mM}), \mathrm{MgCl}_{2}(5 \mathrm{mM})$ and LgGalK $(0.17 \mu \mathrm{g})$ in Tris buffer $(50 \mathrm{mM}, \mathrm{pH} 9.0)$. The initial velocity was calculated by determining the slope of linear phase in the progress curve over $5 \mathrm{~min}(1 \mathrm{~min}$ intervals). All assays were performed in triplicates. The data were fitted to the Michaelis-Menten equation and apparent kinetic parameters were calculated by GraphPad Prism 7.03.

\section{Substrate specificity of LgGalK}

The typical assay for sugar substrate specificity was carried out in a total volume of $50 \mu \mathrm{L}$ of Tris buffer (50 mM, pH 9.0) containing different monosaccharides 1, 6-27 (8 $\mathrm{mM}), \operatorname{ATP}(10 \mathrm{mM}), \mathrm{MgCl}_{2}(5 \mathrm{mM})$ and $\mathrm{LgGalK}(13.6 \mu \mathrm{g})$, at $50^{\circ} \mathrm{C}$ for $2 \mathrm{~h}$. The same reaction mixture and conditions were utilised for the phosphate donor specificity study, except for using various nucleotide phosphates instead of ATP (and only 1 as sugar substrate). The reactions were quenched by heating at $95-100^{\circ} \mathrm{C}$ for 5 min followed by centrifugation at $12000 \mathrm{rpm}$ for $5 \mathrm{~min}$. The supernatant was analysed by silica gel thin-layer chromatography (TLC) developed with $n-\mathrm{BuOH} / \mathrm{AcOH} / \mathrm{H}_{2} \mathrm{O}$ 2:1:1 and stained with $p$-anisaldehyde $\left(6 \mathrm{~mL} p\right.$-anisaldehyde, $10 \mathrm{~mL}$ conc. $\mathrm{H}_{2} \mathrm{SO}_{4}$ and 2 $\mathrm{mL} \mathrm{AcOH}$ dissolved in $180 \mathrm{~mL}$ EtOH). Kinase activity of LgGalK against substrates 1, 3, 6-13, 15, 27 was also further confirmed by HRMS. The supernatant was diluted 10-fold in HPLC grade water, a sample $(2 \mu \mathrm{L})$ was flow-injected into $\mathrm{MeCN} / \mathrm{H}_{2} \mathrm{O} 1: 1$ (+0.1\% formic acid) for analysis on an Agilent 1200 series LC system coupled to an Agilent 6520 QTOF mass spectrometer (ESI negative mode). The conversions of the fluorinated substrates (13-16) were measured by ${ }^{19} \mathrm{~F} N M R$, by diluting the supernatant $(50 \mu \mathrm{L})$ with $\mathrm{MeOH} / \mathrm{H}_{2} \mathrm{O} 1: 1(450 \mu \mathrm{L})$ with addition of a sealed glass 
capillary containing $\mathrm{D}_{2} \mathrm{O}$ for the lock. The conversions of non-fluorinated substrates $(\mathbf{1}, \mathbf{6 - 1 2}, \mathbf{1 7 - 2 7})$ were measured by the DNS assay.

\section{Chemoenzymatic synthesis of 6-aminogalactose-1-phosphate analogues}

One-pot two-enzyme synthesis of 6-oxogalactose-1-phosphate (30) and 2fluoro analogue (31). The reaction mixture containing sodium phosphate buffer (35.5 $\mu \mathrm{L}, 100 \mathrm{mM}, \mathrm{pH} 7.4)$, substrate 1 or $13(4 \mu \mathrm{L}, 100 \mathrm{mM})$, horseradish peroxidase $\left(1.5 \mu \mathrm{L}, 1 \mathrm{mg} \mathrm{mL}^{-1}\right)$, catalase $\left(1.0 \mu \mathrm{L}, 1 \mathrm{mg} \mathrm{mL}^{-1}\right)$ and GOase-M $(1.0 \mu \mathrm{L}$, $\left.9.4 \mathrm{mg} \mathrm{mL}^{-1}\right)$ was incubated at $25^{\circ} \mathrm{C}, 300 \mathrm{rpm}$ for $2 \mathrm{~h}$. Then, ATP $(2.5 \mu \mathrm{L}, 200 \mathrm{mM})$, $\mathrm{MgCl}_{2}(2.5 \mu \mathrm{L}, 100 \mathrm{mM})$ and LgGalK $\left(2 \mu \mathrm{L}, 6.8 \mathrm{mg} \mathrm{mL}^{-1}\right)$ were added to reach the total volume of $50 \mu \mathrm{L}$ and incubated at $50^{\circ} \mathrm{C}$ for $2 \mathrm{~h}$. The reaction was stopped by removing the enzymes through a vivaspin column (10 kDa molecular weight cut-off), centrifuged at 12000 rpm for 5 min. Products 30 and 31 were analysed by ${ }^{13} \mathrm{C}$ NMR or ${ }^{19} \mathrm{~F}$ NMR and HRMS (ESI negative mode).

One-pot three-step chemoenzymatic synthesis of 6-aminogalactose-1phosphate analogues (32a-0 and 33a-0). The enzymatic reaction mixture and process were the same as described above for the preparation of 30 and 31 . After the removal of proteins, 15 different amines $(2.0 \mu \mathrm{L}$ or $2.0 \mathrm{mg})$ were added into each reaction mixture. $\mathrm{AcOH} / \mathrm{H}_{2} \mathrm{O}(1: 1)$ was added to adjust the $\mathrm{pH}$ around 7.0 , followed by a solution of $\mathrm{NaBH}_{3} \mathrm{CN}(5.0 \mu \mathrm{L}, 1 \mathrm{M})$. The mixture was incubated at $25^{\circ} \mathrm{C}$ for $20 \mathrm{~h}$. Products 32a-0 and 33a-0 were analysed by HRMS (ESI negative mode).

\section{Acknowledgements}

This work was supported by the BBSRC, EPSRC and InnovateUK: IBCatalyst programme [BB/M02903411 and BB/M028836/1] and Marie Skłodowska-Curie Innovative Training Network [H2020-MSCA-ITN-2014-ETN-642870]. We gratefully acknowledge Dr. Reynard Spiess and Dr. Matt Cliff for their invaluable help and support with HRMS and NMR analyses, respectively.

\section{References}

[1] F. Nicotra, Carbohydr. Mimics Concepts Methods. 1998, 67-86.

[2] D. Hoffmeister, J. Yang, L. Liu, J. S. Thorson, Proc. Natl. Acad. Sci. U. S. A. 2003, 100,13184-9.

[3] H. G. Hers, Biochem. Soc. Trans.1984, 72, 729-735.

[4] J. Liu, Y. Zou, W. Guan, Y. Zhai, M. Xue, L. Jin, X. Zhao, J. Dong, W. Wang, J. Shen, P. G. Wang, M Chen, Bioorganic Med. Chem. Lett. 2013, 23, 3764-3768.

[5] Y. Zou, M. Xue, W. Wang, L. Cai, L. Chen, J. Liu, P. G. Wang, J. Shen, M. Chen, Carbohydr. Res. 2013, 373, 76-81.

[6] M. M. Muthana, J. Qu, Y. Li, L. Zhang, H. Yu, L. Ding, H. Malekan, X. Chen, Chem. Commun. 2012, 48, 2728-2730.

[7] K. L. Ross, C. N. Davis, J. L. Fridovich-Keil, Mol. Genet. Metab. 2004, 83, 103-116. 
[8] H. Yu, V. Thon, K. Lau, L. Cai, Y. Chen, S. Mu, Y. Li, P. G. Wang, X. Chen, Chem Commun 2010, 46, 7507-7509.

[9] A. Ravidà, X. Liu, L. Kovacs, P. H. Seeberger, Org. Lett. 2006, 1-13.

[10] L. J. G. Edgar, S. Dasgupta, M. Nitz, Org. Lett. 2012, 14, 4226-4229.

[11] O. J. Plante, R. B. Andrade, P. H. Seeberger, Org. Lett. 1999, 1, 211-214.

[12] J. H. Schrittwieser, S. Velikogne, M. M. Hall, W. Kroutil, Chem. Rev. 2017, DOI: acs.chemrev.7b00033.

[13] S. P. France, L. J. Hepworth, N. J. Turner, S. L. Flitsch, ACS Catal. 2017, 7, 710-724.

[14] J. L. Andreassi, T. S. Leyh, Biochemistry 2004, 43, 14594-14601.

[15] H. M. Holden, I. Rayment, J. B. Thoden, J. Biol. Chem. 2003, 278, 43885-43888.

[16] D. Timson, R. Reece, BMC Biochem 2003, 4, 16.

[17] F. J. Ballard, Biochem. J. 1966, 98, 347-352.

[18] D. G. Walker, H. H. Khan, Biochem. J. 1968, 108, 169-175.

[19] X. Chu, N. Li, X. Liu, D. Li, J. Biotechnol. 2009, 141, 142-146.

[20] D. J. Timson, R. J. Reece, Biochimie 2002, 84, 265-272.

[21] J. Yang, X. Fu, Q. Jia, J. Shen, J. B. Biggins, J. Jiang, J. Jiang, J. Zhao, J. J. Schmidt, P. G. Wang, J. S. Thorson, Org. Lett. 2003, 5, 2223-2226.

[22] M. Chen, L. L. Chen, Y. Zou, M. Xue, M. Liang, L. Jin, W. Y. Guan, J. Shen, W. Wang, L. Wang, J. Liu, P. G. Wang, Carbohydr. Res. 2011, 346, 2421-2425.

[23] L. Li, Y. Liu, W. Wang, J. Cheng, W. Zhao, P. Wang, Carbohydr. Res. 2012, 355, 35-39.

[24] S. P. Li, W. C. Hsiao, C. C. Yu, W. T. Chien, H. J. Lin, L. D. Huang, C. H. Lin, W. L. Wu, S. H. Wu, C. C. Lin, Adv. Synth. Catal. 2014, 356, 3199-3213.

[25] M. M. Muthana, J. Qu, Y. Li, L. Zhang, H. Yu, L. Ding, H. Malekan, X. Chen, Chem. Commun. 2012, 48, 2728-2730.

[26] H. Yu, V. Thon, K. Lau, L. Cai, Y. Chen, S. Mu, Y. Li, P. G. Wang, X. Chen, Chem Commun 2010, 46, 7507-7509.

[27] L. Li, Y. Liu, T. Li, W. Wang, Z. Yu, C. Ma, J. Qu, W. Zhao, X. Chen, P. G. Wang, Chem. Commun. 2015, 51, 10310-10313.

[28] X. C. Duan, H. Chen, F. F. Liu, L. Conway, S. Wei, Z. P. Cai, L. Liu, J. Voglmeir, Anal. Chem. 2015, 87, 9546-9550.

[29] L. Sun, I. P. Petrounia, M. Yagasaki, G. Bandara, F. H. Arnold, Protein Eng. 2001, 14, 699704.

[30] D. J. Namdjou, B. Sauerzapfe, J. Schmiedel, G. Dräger, S. Bernatchez, W. W. Wakarchuk, L. Elling, Adv. Synth. Catal. 2007, 349, 314-318. 
[31] C. E. Kupper, R. R. Rosencrantz, B. Henßen, H. Pelantová, S. Thönes, A. Drozdová, V. Křen, L. Elling, Beilstein J. Org. Chem. 2012, 8, 712-725.

[32] B. Thomas, X. Lu, W. R. Birmingham, K. Huang, P. Both, J. E. Reyes Martinez, R. J. Young, C. P. Davie, S. L. Flitsch, ChemBioChem 2017, 18, 858-863.

[33] G. S. Mahuku, Plant Mol. Biol. Report. 2004, 22, 71-81. 